\title{
CONJUNCTIONS:
}

TRANSDISCIPLINARY JOURNAL OF CULTURAL PARTICIPATION

CONJUNCTIONS, VOL. 6, NO. 1, 2019, ISSN 2246-3755

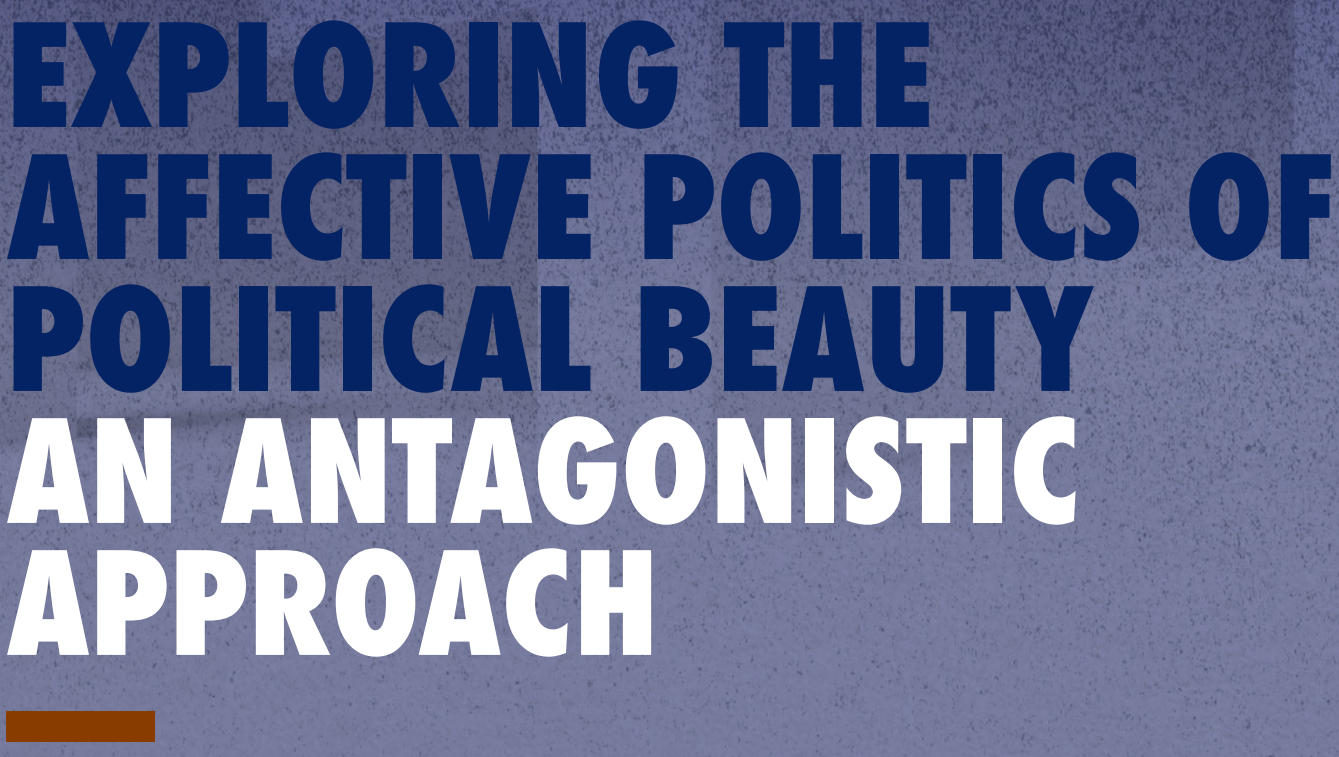

\section{FRIEDERIKE LANDAU}

CORRESPONDING AUTHOR: FRIEDERIKE LANDAU, POSTDOCTORAL REGEARCHER AT SIMON FRASER UNIVERSITY. EMAIL: FRIEDERIKE.LANDAU@METROPOLITANSTUDIES.DE

( ) 2019. FRIEDERIKE LANDAU. THIS IS AN OPEN ACCESS ARTICLE DISTRIBUTED UNDER THE TERMS OF THE CREATIVE COMMONS ATRRIBUIION-NON COMMERCIAL 3.0 UNPORTED LICENSE (HITP://CREATIVECOMMONS.ORG/LICENSES/BY-NC/3.0/), PERMIIIING ALL NON-COMMERCIAL USE, DISIRIBUIION, AND REPRODUCIION IN ANY MEDIUM, PROVIDED THE ORIGINAL WORK IS PROPERLY CIIED.

CITATION: CONJUNCTIONS: TRANSDISCIPLINARY JOURNAL OF CULTURAL PARIICIPATION, VOL. 6., NO. 1, 2019 DOI: HIIP://DX.DOI.ORG./10.7146/TJCP.V611.117316 


\section{KEYWORDS}

ANTAGONISM, AFFECTIVE POLIIICS, POST-POLITICS, AFFECT, POLIIICAL BEAUTY, ZENIRUM FÜR POLIISCHE SCHÖNHEIT, CENIER FOR POLIIICAL BEAUTY

\section{ABSTRACT}

TO UNDERSTAND THE INTRICATE INTERCONNECTION BETWEEN POLIIICS AND AFFECTS, I EXAMINE A PERFORMANCE OF THE BERLIN-BASED ARTIST COLLETIVE ZENTRUM FÜR POLIIISCHE SCHÖNHEIT (CENTER FOR POLITICAL BEAUTY, ZPS), IN WHICH ARTIST ACTIVISTS STAGED A HORSEBACK RIDE TO FASTEN A MANIFESTO OF IEN THESES OF POLIICAL BEAUTY OW THE FACADE OF THE GERMAN BUNDESTAG. INIERCONNECTING THEORIES OF POLIIICAL DIFFERENCE (MARCHART 2010), WHICH DIFFERENTIATE BETWEEN THE ONTOLOGICAL REALM OF 'THE POLIICAL' AND ONIIC REALZATIONS OF "POLIIICS", AND POLIIICAL THEORIES OF AFFECI, I APPROACH THE AFFECIIVE DIMENSIONS OF POLIIICAL DIFFERENCE AS AFFECTIVE POLIIICS. BUILDING ON BARGEZZS (2014) "POLIIICAL GRAMMAR OF FEELINCS", I SITUATE THE PERFORMANCEIS TEMPORARY INSTITUHIONS AND INTERRUPIIONS OF "POLIIICS' AND 'THE POLIIICAL', AS WELL AS 'FEELING POLIIICS" AND 'POLIIICS OF FEELING' RESPECTIVELY, AS AFFECTIVE ENCOUNTERS TO EXPERIENCE OR ENACT POLITICAL BEAUTY. POLIIICAL BEAUTY, IN AN ANTAGONISTIC FRAMEWORK THAT FOREEROUNDS CONHINGENCY, CONFLICT AND ABSENCE, MOBILZZS AFFECTS AS INHERENTLY AMBIVALENT AND CONHENHIOUS. AS A CHALLENGE 10 THE DIAGNOSIS OF AN INEVITABLE POST-POLIICAL CONDITION, I DISCUSS THE POTENTIAL OF POLIIICAL BEAUTY AS AFFECIIVE POLIICS TO POIENHILLYY RE-POLIIICIZE POLIIICS. BORROWING FROM DERRIDA (1994), I CONDUCI A SPECIRAL READING OF ZPS" TEN THESES AND CARVE OUT THREE ANALYTICAL VICNETIES - BEAUTY, VITALITY AND LONGING - TO CONCEPTUALZE POLIIICAL BEAUTY AS OSCILLATING BETWEEN THE DESIRE AND HOPE FOR POLIIICAL CHANGE, WHICH CAN NEVER BE FULLY SATISFIED, AND A DISMISSAL OF (POLIICAL) UGLINESS AND DEATH. IN THE END, POLIIICAL BEAUTY ESCAPES A DEFINIIION BECAUSE IT IS, AFIER ALL, NOTHING BUT AW IMPOSSIBLE PROJECT FOR POLIIICS AND AFFECTS OF AN UNKNOWN FUTURE.

\section{AUHOR BIOGRAPHY}

DR. FRIEDERIKE LAWDAU IS CURRENILY A POSTDOCTORAL RESEARCH FELLOW AT SIMON FRASER UNIVERSITY, VANCOUVER, AND ASSOCIATE FELIOW AT THE CENTER FOR METROPOLITAN STUDIES, TECHNICAL UNIVERSITY OF BERLIN. HER RESEARCH IS SITUATED AT THE INIERSECTION BETWEEN POLIILCAL AWD SPATIAL THEORY, CULTURAL POLICY AND URBAN GOVERNANCE. FRIEDERIKE IS INTERESTED IN CONCEPTUALIZING FORMS OF ARTISTIC ACIIVISM AS DIVERSE FORMS OF 'THE POLIIICAL', RANCING FROM SENSE-BASED ARTISTIC TACTICS TO POLIICAL MOBILZATIONS IN PUBLIC SPACES AND ARTISTS' POLICY INTERVENTIONS. IN HER DISSERTATION, FRIEDERIKE EXPLORED THE EMERGENCE AND POLIIICAL ORGANISATION OF BERLIH-BASED ARTISTS AND CULTURAL WORKERS. HER MONOGRAPH AGONISTIC ARTICULATIONS IN THE 'CREATIVE' CIIY - ON NEW ACTORS AWD ACIIVISM WAS PUBLISHED WIHH ROUHLEDGE IN 2019 (SERIES POLIICAL SOCIOLOGY). CURRENTLY, FRIEDERIKE IS CO-EDINING THE BOOK [UN]GROUNDING - POST-FOUNDATIONAL INTERVENIIONS IN SPACE TO BE PUBLSHED IN SEPTEMBER 2020. THIS VOLUME AIMS TO ESTABLISH A CONVERSATION BETWEEN POST-FOUNDATIONAL POLIICAL THEORY AWD RADICAL GEOGRAPHIES AND SPATIAL THEORY TO DEVELOP AN UNDERSTANDING OF SPACE AS INSTITUIED FROM CONTINGENCY, CONFLICT AND ABSENCE. FRIEDERIKE HAS RECENILY BEEN INVESTICATING MUSEUMS AS RADICAL DEMOCRATIC INFRASTRUCTURES IN URBAN CONIEXIS, CHARTING MUSEUMS' PLACE-MAKING PRACIICES AS POTENTIAL AVENUES TO (RE)ARTICULATE MOMENTS OF THE POLIICAL'. 


\section{Introduction: Politicizing (Post-)Politics}

Have you heard politics is dead? Did you know we live in an age after politics? Recent debates in political and cultural theory as well as critical urban studies have captured tendencies of growing political disenchantment, indifference, lack of engagement and crumbling trust in political parties under the umbrella term 'post-politics' or post- democracy (Crouch 2014; Mouffe 2005; Swyngedouw 2009, 2011, 2016; Swyngedouw and Wilson 2014; Rancière 2010; Žižek 2009a; 2009b). Seemingly ever-expanding, and slowly becoming intangible, the post-political is diagnosed as manifesting itself in the increasing bureaucratization, technocratization and rationalization of politics. The lack of political alternatives, similar to Margaret Thatcher's TINA paradigm, 'There is no alternative', is often proclaimed. Simultaneously, consensus is posited as an intractable value, while conflict is presented as a problem for or hindrance to political life. Post-politicization might well be empirically observable in entrepreneurial modes of urban governance. For example, transnational crises of migration, spatial displacement and populism are tamed with management tactics or economic incentives rather than considered humanitarian crises which need responses of solidarity and collectivity. In brief, the diagnosis of post-politics is not unproblematic itself.

Highlighting this political dimension which is inherent in the announcement of post-politics, scholars have criticized the seeming omnipresence and irrefutability of the post-political (Beveridge 2017; Davidson and Iveson 2014). Beveridge and Koch $(2016,37)$ warn against the 'post-political trap' which fortifies the discursive dominance of the post-political condition. Similarly, Larner $(2015,192)$ argues that Swyngedouw is to be turned "against himself, to argue that the post-political and post-democratic configuration accepted at face value (...) [it] must itself be re-politicised as a 'matter of concern', not presupposed as a 'matter of fact'." This Latour-inspired appeal to attend to the post-political as 'matter of concern' rather than an objectivized 'matter of facts' interrelates with my objective to challenge the seemingly uncontestable status of the post-political. What does it mean then to consider post-politics as a matter of concern? What kind of concern or what kind of feelings might the post-political elicit? To further our understanding of post-politics as a matter of concern, I turn to the concept of political beauty as a potential means to express and ignite a concern for (post-)politics.

My approach to addressing this is two-fold: First, I explore the notion of political beauty, most prominently put forward by the Berlin-based artist-activist collective Zentrum für Politische Schönheit (ZPS; Center for Political Beauty). I will carve out how ZPS understands and advocates for political beauty via a close reading of their founding document, the ten theses of political beauty. After contouring the definitional features of political beauty, in a second step, I will discuss the potential of political beauty as a means to contest post-politics. In this speculative endeavour, I focus particularly on the affective dimension of political beauty. By this I mean the emotional or sensory implications of talking about, and more importantly, doing politics as a way to push back against the supposed default status of the supposed post-political. The artist collective ZPS serves as a case study to illuminate the aspirations and hopes of what political beauty could, should or could not do in relation to the (post-)political.

Depending on the nature and degree of publicity of their performance - be it in public space, hosted in different locations or online - ZPS is a collective made up of a fluctuating number of artists, intellectuals, scholars or 'accomplices', as they call themselves. Spearheaded by philosopher Dr. Philipp Ruch, ZPS has attracted controversial reactions in national and international newspapers. Their activities have been interpreted as a new form of action art, performance art or artistic activism, characterized as "aggressive humanism" (Bayrischer Rundfunk 2014). Taking this aggressive humanism as a literal way to radically contest political disenchantment, ZPS stages actions such as 'Säule der Schande' (Column of Shame; 2010), in which they piled up 16,744 shoes, representing 8,372 victims of the genocide in Srebrenica, Bosnia, in front of the Brandenburg gate.' Another action was called 'Die Toten kommen' (The Dead are Coming; 2015), in which the group removed white crosses, which commemorate casualties who died at the former German-German border, to bring them to Europe's southern frontier to evoke a sense of scandal about the recent reconstruction of borders in Europe (see Landau 2019b). Besides drawing attention to the political passivity of European leaders, the group is subject to ongoing legal processes disputing whether ZPS' actions fall under the expression of artistic freedom or whether they are to be considered a criminal organization (MDR Thüringen 2019). Beyond the group's concrete actions, in this article, I engage with the group's first and so-far only written expression of a political stance of their mission of spreading political beauty.

Ruch (2012b, 95), the most publicly visible and articulate speaker of the group, considers the necessity of beauty and Sehnsucht (i.e., longing or desire) as political ideals, resources and 'commodities' to design and change society. Against the 
Thatcherite TINA slogan, and via their unconventional, controversial and disputedly legal actions, ZPS shows that there are, in fact, alternatives for present and future political actions, choices and imaginaries. The activists of ZPS understand the future as the 'breeding ground' for creating the highest form of art, which Ruch (2012b) considered to be politics. I proceed by scrutinizing the links between politics, or post-politics, and beauty in the conceptual trope of political beauty. To understand the potential of political beauty in the context of the post-political, or as a means to re-politicize politics, I introduce the framework of political difference. By differentiating between politics and the political, I aim to open an analytical space for discussing and experiencing articulations of the political beyond narrowly defined categories of what politics is. Moreover, the sensitivity of a difference-oriented understanding of politics aims to mobilize a space to consider the emotional and affective dimensions of politics.

\section{Political Difference - Making Space for Antagonism}

Theories of political difference (Marchart 2010; Mouffe 2005) distinguish between the political and politics. While the political underlines the irreducibly antagonistic dimension inherent in more-than-human relations, manifestations of politics describe routinized, repetitive and regimented practices and procedures to enact decisions for social and institutional systems. Hence, politics encapsulate sedimented and normalized rules and behaviors. The political, in contrast, appeals to the ineradicable and constitutive dimension of antagonism or conflict in politics. This antagonism is radical and necessary; it can only temporarily be transformed into tamed forms of antagonism, which have been conceptualized as agonism (Mouffe 2013). The framework of political difference and antagonism is developed in post-foundational political thought (Laclau and Mouffe 2001; Landau 2019a; Marchart 2010). Post-foundationalism assumes that there 'is' no foundation, ultimate reason or necessity to politics or society. Instead, political and social meanings and institutions are results of temporary and precarious articulations. In other words, all forms of politics emerge from the political, which is situated in a radical negativity or absence of last grounds (again, there 'is' no a priori reason or meaning to political positions or identities). It follows that contingency and antagonism, which captures the constitutive conflictuality of political life, are necessary components of a theory of antagonism. In the face of this radical absence, the political (temporarily) emerges and aims to occupy the generally "empty place of power" (Lefort 1988). Because power can never be grasped fully, or definitively, all attempts at making new meaning, or suggesting new ways of politics remain fragmented. It is in this context that I discuss the potentials of political beauty to form new ways of expressing the political, or politics. The desire or longing implicated in and evoked by the call for political beauty brings up the question of what makes us consider politics to be beautiful (or not). As aesthetic experience of beauty (whatever that is; we still do not know for now) are not objective or purely intellectual or cognitive, but rather bodily, sensory and emotional, the discussion of the political rigor of political beauty needs to be addressed with regards to its affective dimensions.

\section{Towards an Antagonistic Understanding of Affect}

The affective turn in social and cultural theory (Gregg and Seigworth 2011; Angerer et al. 2015) has foregrounded the role of individual feelings, emotions, passions as well as trans-individual expressions of affect. ${ }^{2}$ To better understand the effects and capacities of political beauty as a bulwark against post-politics, or a trigger for politicization, I examine the connections between affects, or affective politics, and antagonism. By delineating an exploratory conceptualization of antagonistic affective politics, I enter unchartered territory in post-foundational thought (Marchart 2010, 438). Even though Chantal Mouffe (2006) has pointed to the importance of passions in politics, the concrete or empirical interactions between passions, emotions or affects on the one hand, and political claims, positions or actions on the other hand, have remained little studied. Borrowing from Spinoza (2009), I set out to understand how states of affecting and being affected condition possibilities to assume power, and how affective power might activate underlying antagonisms. When antagonisms become visible or sensible (again), Protevi (2009) argues that these political affects might contribute to articulating new forms of political belonging, agency and community. 1 triangulate existing political theories of affect (Anderson 2014, 2016; Ahmed 2015) and elaborations on the politics of affect (Massumi 2015) to tentatively sketch a theory of affective politics which captures the political difference of affective politics, or 
the ontologically 'negative', antagonistic dimensions of affect. So, if affects are political, and potentially antagonistic, we gain a sense of politics as similarly affective. In other words, if politics are necessarily antagonistic and affective, conflicts are also affective experiences - struggles upset us, relieve us, make our hearts pound, make us cry, give us new hope. Vice versa, affects or emotional and bodily impressions are principally contested - somebody's touch might feel exciting to some, while frightening to others; spatial proximity might cause anxiety in one and give a feeling of home and safety to others. Most generally, affects (and emotions) are never unilaterally good or bad. Negative feelings such as displeasing states of distress, including anxiety, depression, aggression, sadness, shame, fear or guilt (Watson et al. 1988) are not necessarily the same for everybody. Also, feelings or affects not per se bad, wrong or generally problematic (Cvetkovich 2012). Instead of pathologizing or vilifying negative feelings, my understanding of negative feelings, or negative affect, stems from the negative ontology or antagonism described above. Just as negative feelings or emotions are not per se bad, being affected by or feeling something is not per se good or politically emancipatory either. Amidst the uncontrollability of which kinds of affects generate which kinds of politics, new possibilities for populist, xenophobic or homophobic politics arise via the mobilization of 'negative' emotions such as fear and anger. On the other end of the spectrum of affective politics, new trans-local networks and associations can emerge from overaching communities carried by feelings of solidarity and compassion (see Bargetz/Freudenschuss 2012). While more awareness about emotions might be politically progressive and divisive, the toning down of feelings, suppression or foreclosure of emotions in politics can spur increasing support for movements and parties that do 'play' on emotions. In addition to the dangers of populist affective politics (whether left or right), queer-feminist scholars have criticized the potential instrumentalization of politics of emotion or empathy to foster neoliberalization, which justifies individualization, de-solidarization and passivization (Pedwell 2012; Berlant 2011). Aware of possible downsides of affective politics, and the incalculable consequences of unleashing affects in politics, I turn to the trope of political beauty, which is nested precisely in these both possibly dangerous and invigorating politics and emotions.

\section{Grinding Grammars of Political Difference and Emotion}

To illuminate the antagonistic framework of affect further, first, I trace the tensions between the political and politics that might be constitutive of the concept of political beauty. Second, I discuss political beauty as inscribed and externalized via a "political grammar of feelings", which hovers between enactments of "feeling politics" and "politics of feelings" (Bargetz 2014a, 2014b). These two conceptual tenets of political difference, and the political grammar of feelings relate to larger discussions about

(post)politics and affects (see Bargetz 2018), and feed into the attempt to conceptualize affective politics with an antagonistic lens. With regard to the mobilization and emergence of feelings that might result in the politicization of politics and the political, or the emergence and experience of beauty, I will examine the role of antagonism in the politics of affect, or affective politics.

Bargetz's (2014b) understanding of a "political grammar of feelings" differentiates between, yet interconnects 'feeling politics' (i.e., the emotional, sensory and perceptual dimensions of feeling as practice) and a 'politic of feelings' (i.e., the power-related dimensions of feelings as construct of collective affects). Feeling politics mobilize modes of "translating relations of power and exploitation into embodied ordinary practices" (Bargetz 2014b, 129). Put differently, feeling politics underscore the experience of affects as bodily inscriptions in everyday experiences and appropriations of both politics in the narrow sense and the political at large. Conceptually, the political grammar of feeling is situated in a framework (or maybe also a grammar of) political difference in that it goes beyond a binary understanding of rationality and emotions. The former becomes sedimented in politics, while the latter might possibly be activated in the realm of the political. More explicitly, the politics of feeling act as "motor and instrument of the political" (Bargetz 2014b, 119). Building on Bargetz' own investment in theorizing the political, I triangulate the tropes of politics/the political and feeling politics/politics of feeling to tease out their shared difference- and ambivalence-oriented, non-binary accounts of the political. To investigate "what affect does politically" (Bargetz 2014a, 301), the post-foundational approach to affect refrains from making any essentializing assumptions about what affect is. Viewing affect as neither unequivocally stimulating political emancipation nor disenfranchisement, affect, after all, remains paradoxical (Cvetkovich 2012; Hemmings 2005).

Taking the example of the ZPS manifesto of the ten theses of political beauty, Table 1 below shows how political and emotional 
differences variously permeate the individual theses. Since both the grammars of political difference and emotion draw on the constitutive parameters of conflictuality and contingency in political and emotional life, I consider them as complementary analytical approaches to contour both politics and affects as antagonistic. This triangulation ultimately flows into a provisional conceptualization of antagonistic affective politics. Before diving into the analysis of the theses, Table 1 unpacks which notions of politics and emotions prevail in the activities and proclamations of politicizing (post-)politics.

Table 1 Tenets of Antagonistic Affective Politics

\begin{tabular}{|c|c|c|c|c|}
\hline \multirow[b]{2}{*}{$\begin{array}{l}\text { Operationalization } \\
\text { of Grammar }\end{array}$} & \multicolumn{2}{|c|}{ Political Grammar of Feelings } & \multicolumn{2}{|c|}{ Political Difference } \\
\hline & Feeling politics & Politics of Feeling & Politics & The Political \\
\hline Grammatical Status & $\begin{array}{l}\text { Feeling as verb, } \\
\text { doing, practice }\end{array}$ & $\begin{array}{l}\text { Feeling as noun, } \\
\text { institution, tool of } \\
\text { power }\end{array}$ & $\begin{array}{l}\text { Politics as noun, } \\
\text { institution, tool of } \\
\text { power }\end{array}$ & $\begin{array}{l}\text { Politics as verb, } \\
\text { doing, practice }\end{array}$ \\
\hline Ontological Status & Ontic & Ontological & Ontic & Ontological \\
\hline Heuristic Description & $\begin{array}{l}\text { Affect as bodily and } \\
\text { sensory experience }\end{array}$ & $\begin{array}{l}\text { Affect as governed } \\
\text { through state/ } \\
\text { politics, but also as } \\
\text { motor for 'emanci- } \\
\text { patory' politics }\end{array}$ & $\begin{array}{l}\text { Politics as regu- } \\
\text { larized, routi- } \\
\text { nized practices of } \\
\text { decision-making } \\
\text { and governing }\end{array}$ & $\begin{array}{l}\text { The Political as } \\
\text { constitutive dimen- } \\
\text { sion of antago- } \\
\text { nism in political } \\
\text { relations }\end{array}$ \\
\hline $\begin{array}{l}\text { Manifestation in theses } \\
\text { of political beauty }\end{array}$ & $\begin{array}{l}\# 3 ; \# 4 ; \# 5 ; \# 6 ; \# 8 ; \\
\# 9 ; \# 10\end{array}$ & $\# 1 ; \# 2 ; \# 3 ; \# 7$ & $\begin{array}{l}\# 3 ; \# 5 ; \# 6 ; \# 9 ; \\
\# 10\end{array}$ & $\# 1 ;$ \#2; \#4; \#9 \\
\hline
\end{tabular}

\section{A Spectral Reading: Approximating Antagonisms in Affective Politics}

I encountered a double bind methodological impasse in the face of both access to and analysis of the ten theses of political beauty. Since this first public intervention of ZPS, called Re-Formation of History, staged on May 8, 2009, has remained little documented in comparison to other, later performances mentioned above, it is difficult to detect the concretely felt or sensed affective responses to and experiences of the performance. Moreover, I did not attend the performance at the time, but only encountered the text many years later, when I first become interested in artistic activism. To avoid equivocation, here, I focus on the textual component of the performance, which crucially excludes other components of the larger affective assemblage of the overall performance (Reestdorff 2015). This assemblage beyond the text was co-constituted by over 130 accidental spectators, who were later sworn in as future heroes in a post-heroic Germany, to suggest a time and nation beyond the heroization of political leaders. In addition, the assemblage mobilizes the potential of the performance to affect, including via significant assemblage components such as the time (i.e., official date of the end of World War II) and place (i.e., in front of the Bundestag, seat of parliamentary power of the German people) of the performance. Despite this possibly constricting reduction to the text or textuality of political beauty, I turn to the written residue of the performance. The ten theses serve as a fragmentary remainder, yet a crucial source to trace what political beauty could mean and/or do with regards to the crisis of (post-)politics outlined above. Understanding the grammars of political difference and emotion as tools to dissect, operationalize and finally navigate through the intricate interpenetrations between politics and emotions, which have always-already been interrelated, I further approximate a notion of antagonistic affective politics. I wonder whether and how ZPS' proclamation of political beauty could be an example of antagonistic affective politics, or whether their own understanding of political beauty thwarts my conceptual 
ambition to think about affective politics in a post-foundational and antagonistic framework? What are the political potentials and dangers of the value and goal of political beauty? How could such beautiful politics manifest affectively and spatially?

With a topological notion of space as generally unsettled (Landau/Roskamm 2018) and a notion of temporality as disrupted and disjointed by pasts of colonial settlerism and genocide (Gordon 2008; Sharpe 216), I approach confluences of past, present and future as haunted temporalities (Derrida 1994). Conjunctions of pasts and futures shape political and affective acts in the present, creating what Homi Bhaba $(1994,254)$ calls a "time lag" between past and future that "keeps alive the meaning of the past." The performance and proclamation of political beauty conjures ghosts which irritate and fuse understandings and crises of past, present and future. Accordingly, my reading of the ten theses is a spectral one, aiming to decipher the ghostly dimensions of texts about politics, affects, places and times (O Riley 2007; Pile 2005; Wylie 2007). While spectral reading is not a certified methodology of social sciences, what I mean to do with this haunted reading of a text full of affects and politics is to detect and make room for unleashing the conflicts, contradictions, or ghosts of antagonism that are latently or manifestly present in political beauty. Moreover, it might help to temporarily disentangle affective qualities of time and space. Couching the spectral reading into emerging discussions about affective methodologies (Knudsen and Stage 2015; Blanco and Peeren 2013; Barad 2003), I consider the theses as affective data to tackle the (im)possibilities of how to make political beauty visible or experiential via text (i.e., data). Data might leave behind traces, which might reveal afterlives of their own (Blackman 2015). In short, by being sensitive and explicit about tracing conflicting notions of time, history, political power and agency, I trace how the theses of political beauty affect 'us', and how 'we' might affect (i.e., transform, embody, appropriate, challenge, question, reject etc.) these proclamations via political actions, feelings and change.

Time, place and affect can not be neatly separated into bodily experiences of affects on the one hand, and responses to affect on the other hand. History and personal experience are similarly indistinct from each other. Conjurations of a historical past, embellished in political beauty, might attend to the silenced, forgotten or suppressed places, hopes, desires and voices of the political. ZPS (2009a, 27) describes one of their goals as excavating "buried" ideals, suppressed wishes and "lost" hopes about politics as crucial resources for future-oriented political action. While the foundational rhetoric of 'excavation' might irritate the post-foundational reader (since the content to be excavated is not essential or unequivocal itself), the invocation of contested pasts functions more as a general impetus to be affected rather than a concrete instruction of what to do or excavate. Hopes and attempts for other possible futures remain insatiable, haunted, ambivalent, entrenched in haunted pasts, presents and politics. In the concrete context of ZPS' performance, the group appeals to the German legacy of genocide and identifies the Holocaust as their "reason to exist" (ZPS, personal conversation, February 27, 2019). In a framework of haunted temporality, historical present is open and malleable, affecting and carrying traces of past and memory (Cvetkovich 2007; Bargetz 2013; Berlant 2010). To sum up these methodological underpinnings of a spectral reading, affecting or affective politics are always imbricated in pasts which might burden texts, or textures of the present (see Slaby 2017 a). In a quest for understanding the potential of antagonistic affective politics to enact and affect antagonisms, the ten theses problematize precisely the political backbones of pasts, presents and futures by invoking political beauty.

\section{Tracing Antagonistic Affective Politics in Political Beauty}

After engaging with notions of politics, the political and the post-political, I finally turn to the spectral reading of the theses of political beauty. For this haunted endeavour, both the grammars of political difference and feelings provide vocabularies for navigating the reading to detect, underline and spell out where and how the antagonistic potential of political beauty emerges. Guided by the tenets of political difference and the political grammar of feelings, I explore where and how negative (i.e., radically antagonistic) affects conjure political beauty. Elisabeth Roberts $(2013,393)$ localizes the ghostly in "'liminal' states, transgressing or oscillating between thresholds, clear-cut categories and binary oppositions." Within this liminality, I scrutinize the theses for their invocations of feeling politics, politics of feelings, expressions and acts of politics and the political. This textual mining is complemented by other texts authored by ZPS members and affect scholars. Note that this reading is itself necessarily haunted, a "speculative interpretation that transforms its own object of investigation" (Derrida 1994, 63).

To wade through the quest to understand and sense what political beauty does or can do, I have abstracted three analytical 
vignettes to systematize and analytically sort the ways in which ZPS appeals to and invokes political beauty. The see-sawing dimensions of VITALITY, BEAUTY and LONGING have been deduced from a systematic review and coding of the frequency of mentions in the text. These analytical topoi serve as a guide through the thicket of the text, and by no means are intended to delineate clear-cut categories or meanings of affect. Undeniably, ghosts linger in texts and readings of texts. By this, I mean that every reader's reading of a text happens and feels differently.

First, references to life, birth, death, vitality and sickness, as well as references to what it 'is', what means to 'be' or feel human or alive or 'have' a soul are subsumed under the vignette VITALITY. ${ }^{3}$ This is the most prevalent category describing political beauty (10 references) and appears in six out of ten theses. Second, references to beauty, and ugliness as its analytical counterpoint, including appeals to poetry and aesthetics, which are subsumed as manifestations of beauty, are captured in the vignette BEAUTY (9 references). Seven out of ten theses underscore the importance and necessity of experiencing (political) beauty. Third, LONGING, (i.e., Sehnsucht) bundles the emotional complex of desire, longing, greatness, perfection and hope (7 references). This longing is mentioned in five out of ten theses. While four theses engage with both BEAUTY and VITALITY (theses \#4, \#6, \#9, \#10), theses \#2 and \#3 engage with BEAUTY and LONGING respectively. Thesis \#5 interconnects all three vignettes.

Table 2 Dismantling Political Beauty = BEAUTY + LONGING + VITALITY

Source: translated by author, based on ZPS 2009a, 26.

\begin{tabular}{|c|c|c|}
\hline & Thesis & Vignette \\
\hline 1 & In every human being, there is a profound desire for the beautiful. & $\begin{array}{l}\text { BEAUTY; } \\
\text { LONGING }\end{array}$ \\
\hline 2 & Everything great is born from desire. & LONGING \\
\hline 3 & $\begin{array}{l}\text { People are not only moved by causes, but also by goals. Beauty, greatness } \\
\text { and perfection are goals. }\end{array}$ & $\begin{array}{l}\text { BEAUTY; } \\
\text { LONGING }\end{array}$ \\
\hline 4 & $\begin{array}{l}\text { Beauty and ugliness are both poles between which life fundamentally takes } \\
\text { place. }\end{array}$ & $\begin{array}{l}\text { BEAUTY; } \\
\text { VITALITY }\end{array}$ \\
\hline 5 & $\begin{array}{l}\text { 'Everyone warms their heart in a different way.' From this, the moderns have drawn } \\
\text { the conclusion to not warm their hearts at all. Without the experience of beauly, } \\
\text { human experiences are incomplete. }\end{array}$ & $\begin{array}{l}\text { VITALITY; } \\
\text { BEAUTY; } \\
\text { LONGING }\end{array}$ \\
\hline 6 & $\begin{array}{l}\text { 'He [sic] treats beauty as entomologists treat butterflies. He catches the poor } \\
\text { animal, he pins it down, and as its exquisite colors drop off, there it lies, a lifeless } \\
\text { corpse under the pin. And what is what they call aesthetics.' (Goethe) }\end{array}$ & $\begin{array}{l}\text { BEAUTY; } \\
\text { VITALITY }\end{array}$ \\
\hline 7 & Hopes are not there to be abandoned. & LONGING \\
\hline 8 & What we know depends on what we feel. & VITALITY \\
\hline 9 & A soul that has not experienced beauty, commits emotional suicide. & $\begin{array}{l}\text { BEAUTY; } \\
\text { VITALITY }\end{array}$ \\
\hline 10 & Souls without poetry are an undiscovered form of mental illness. & $\begin{array}{l}\text { BEAUTY; } \\
\text { VITALITY }\end{array}$ \\
\hline
\end{tabular}

Thesis \# 1 grandly proclaims political beauty as a desire, a "profound", seemingly unavoidable desire. Situating political beauty as innate to humankind, but without specifying what that beauty entails, political beauty remains an abstract category. While the setting of political beauty as an inherent human capacity and affect could seem deterministic or foundationalist in the sense of assuming an essence of political beauty, the concept remains somewhat void of meaning. With regards to the post-foundational framework tested in this paper, the first thesis does not propose a clear mandate or scope of what political 
beauty 'is'. Thesis \#2 situates the origin of greatness as "born from desire." Desire appears as the (only) source or location from whence greatness, and thus potentially political beauty, emerges. As the spatial connotation of desire as origin or foundation of greatness might again sound foundational or totalizing, desire could be understood as a sedimentation (i.e., a reified and normalized construction of meaning and power). However, the transcendental-sounding, grand category of 'greatness' suspends any determinate content of both desire and greatness, leaving the reader again clueless about what greatness 'is'. While Ruch (2012a, 230) claims political beauty as desire or "appetite or thirst" which "must be satisfied," the complete satisfaction or attainment of this desire remains barred. Arguably, this utterly totalizing claim that everything great emerges from desire exceeds its own claim, making the emergence from desire necessary, but also ultimately unattainable. Thesis \#3 challenges the dialectics of cause and effect/goals by stating that people "are not only moved by causes, but also by goals." However, these goals remain unspecified; political beauty is charged with the affective or even causal capacity "to literally move people" (Ruch 2012a, 216). This inversion of cause and effect not only leads to the dismantling of rationality as a hindrance to political beauty, but also subtly uncovers a post-positivist understanding of political beauty as a value beyond rationality. The values of "beauty, greatness and perfection" appear as placeholders for an affective struggle for political beauty (yes, it is still unclear what any of these terms really mean). However, via the concurrent function and activity of beauty, greatness and perfection as both cause and affect/effect/goal, LONGING gains traction as a powerful component to leverage not only BEAUTY, but political beauty. Note that Thesis \#8 also engages with a proposition about causality, explicating that "what we know depends on what we feel." This reference showcases the affective epistemology of political beauty, which makes knowledge possible only when we feel it. While neuro-psychology and social and cultural theoretical interpretations have problematically separated cognition and feelings (Leys 2011), ZPS' manifesto claims that knowledge is inseparable from feeling and/or affect. In extrapolation, there 'is' no knowledge without affecting or being affected, we cannot know without feeling. Via being affected, and affecting, humankind comes to know or learn. In line with the feminist refusal to divorce ontology and epistemology (Hemmings 2005; Barad 2003), Thesis \#8 liquefies the problematic "dispositive of separation" between emotion and rationality or politics (Bargetz 2014b), and instead suggests something like a 'dispositive of ambiguity' between politics and affects as simultaneous causes and goals. Moreover, this dispositive of ambiguity rejects the assumption that affects and/or emotions are autonomous or a-signifying psychological reactions. Ruch (2012a, 221) problematizes political science's neglect of the category of beauty, and its omission in relation to its engagement with moral ugliness, decay or nihilism. Regardless of Ruch's awkward dismissal of psychoanalytical or otherwise 'negative' theories to understand human behavior, it becomes clear that desire and longing are unavoidable to know political beauty.

Thesis \#4 positions beauty and ugliness as the poles between which life takes place. While the thesis seemingly reproduces a binary opposition, and an irritably conservative one, BEAUTY and VITALITY are reintroduced as affective approaches and dimensions of life that are to culminate in politically beautiful life. Without being spatially fixed or filled with any concrete content, life as a sub-category of VITALITY hovers between beauty and its counterpart of non-beauty or ugliness. In other words, political beauty seems to depend on life and death, and is a matter of both. The reference to the fundamental, or 'foundational' location life between beauty and ugliness evokes the question of normative direction, location or effect of either of the two. However, life seems to be made not only of beauty alone (or ugliness for that matter, either). Rather, political life and beauty are permeated by lack, as annotated by LONGING in the previous thesis. As Paul Harrison $(2015,5)$ states, "life is always already involved with loss, just as fire requires fuel". Acknowledging the inevitable presence of death in life, Harrison (2015, 28) goes on to argue that the "more one thinks about life outside death, the more the ghosts multiply". This notion mobilizes political beauty as a haunted concept which projects life and death, beauty and ugliness, inseparably married to each other. To conclude, Thesis \#4 marks the spaces between beauty and non-beauty, which remain affectively, temporally and spatially indeterminate, yet positions 'life' in the largest sense of the term as a crucial component of political beauty. ${ }^{4}$

In Thesis \#5, the advocacy for life and living (i.e., VITALITY) is developed by drastically stating that life without beauty means lack, or incompletion. While it stresses the manifold ways to affect and be affected - "everyone warms their heart in a different way" - it positions beauty as a necessary category for "human experience." Inversely, life without beauty would not be possible. While beauty might remain incomplete, it cannot be foreclosed from political life. In light of the objective to understand antagonistic affective politics, both the necessity and contingency of political beauty shine through. While the reference to experiential, affective knowledge in Thesis \#5 remains implicit (see Thesis \#8 above for the explicit connection between knowledge and affect), Thesis \#5 strongly appeals against political and emotional indifference. The practice of heart-warming 
seems a necessary affective practice or experience to access political beauty. Notably, this thesis constitutes the unique nexus of all three analytical vignettes, showing that LONGING remains unsatisfied and VITALITY or life remain incomplete without political BEAUTY. The possibility to satisfy desire, and to live life depend on political beauty, but the shape and meaning of their confluent accomplishment remains radically ambivalent and antagonistic.

Thesis \#6 intensifies the bond between VITALITY and BEAUTY, referring to the importance of affective liveliness to be activated from the striving for political beauty, or in this case, aesthetics. The metaphor of "nailing down" beauty, or reifying it, which results in having to take responsibility for creating a "lifeless corpse" of deceased beauty uncovers the irreducible bond between the never-ending quest for political beauty and 'being', or 'becoming' alive. Political beauty is only intact if it stays alive, in motion, dislocated, indeterminate. In contrast, the attempt to hunt down beauty kills off the very object of desire. In brief, political beauty needs to exist in a state of being unsettled, to remain contingent, ambivalent and not dead. This thesis again marks the hauntological dimension of political beauty as imbricated in both LONGING for life, but beyond a mere obsession with VITALITY, also entangled with different states of death, present and past.

Thesis \#7 introduces hope as a crucial facet of desire or LONGING, stating that "hopes are not there to be abandoned." Like political beauty, hope needs to 'live on' and remain open so that political beauty remains possible. Without desire or hope, there is no chance of political beauty. At the same time, this thesis does not mention the request or appeal to hope to be fully translated or attainable. Just like the butterfly mentioned in Thesis \#6, hope cannot be nailed down. Put differently, LONGING elicits both the possibility and impossibility or unattainability of political beauty. Political beauty remains desired and desirable despite and because of ongoing unstilled desire. Understanding desire as revolutionary and pre-individual, as well as excessive, Claire Colebrooke $(2014,116)$ describes longing as the "force from which social relations emerge; even if all social forms emerge from desire, desire also exceeds the systems that it has generated itself." Hence, besides the relation-building or social aspect of desire, there is something uncontrollable, radical, intangible, antagonistic about LONGING. While hopes are not there to be abandoned, they are also not there to 'be' fully achieved. With regards to the disrupted temporalities of political beauty, Thesis \#7 activates hope for both the future and the present, situating hope as a crucial, yet malleable cornerstone for political beauty and action. While the call for hope might come across as naïve or simplistic, the invocation of hope stems from a disrupted or disruptive temporality of interwoven pasts, presents and futures. ZPS advocates for a "future II" (i.e., one that 'will have been') to point to the political potential of the future. On the one hand, future is marked by radical openness and an absence of any determinate course of action or politics. On the other hand, the politics of the future are nested in legacies of forgotten political and aesthetic hopes as well as histories of political beauty and ugliness. As political beauty is bound up with the present and past, with those who will benefit from it in the future and those who could have benefitted from it, political beauty in a scenario of future II stitches together future and present in the desire or LONGING for political change that 'will have happened.' This kind of future operates, as Avery Gordon (2011, 2) states, as if "it has already been needed or wanted before, perhaps forever, certainly for a long time, and we cannot wait for it any longer". At last, Thesis \#7 creates a sense of urgency and critique of having 'forgotten' both individuals' awareness of their own beliefs and former visions, but also extends criticism to the general political apparatus, accused of having neglected the origins of political visions, motives and objectives. In this claim, ZPS explicitly works against political disenchantment, and against the alleged end of history or politics. Drawing on Laclau, the (re)activation of insatiable desire or LONGING as a source for political engagement and change might led to dislocate the sedimented origins of politics (i.e., emblematized in the built environment of the German Bundestag where the performance took place). Intervening in this assumedly smooth space of politics, the request for political beauty disturbs the hegemonic rule of politics in favor of unleashing a sense of the political at large.

Vitalist undertones of political beauty are further explicated in Thesis \#9, which proclaims that life without beauty leads to death. The dramatic metaphor of "emotional suicide" vividly describes political beauty as a self-induced and agential affect and, at the same time, pathologizes the non-experience or rejection of political beauty. The glorification of VITALITY seems to oppose the engagement with ethical concerns about negativity, or an ethics after affirmation (Harrison 2015). This one-sided, non-ambivalent celebration of beauty might be hard to bear in a post-foundational framework. The outlined antagonistic approach to affective politics would systematically refrain from equating beauty with goodness, desirability, or even liveliness. Similarly, the spectral framework sits uncomfortably with the obsession to enjoy political beauty because it is vital. While the value of political beauty might remain void of concrete or instructional content, it does explicitly pathologize negative feelings such 
as the death drive or, more implicitly, depression (Cvetkovich 2012). The problematic connotation of the politically beautiful "soul" reveals not only its promissory drive, but also uncovers the costs of this "cruel optimism" (Berlant 2011), which prolongs a state of happiness and political beauty into the future. This seemingly humanistic belief might complicate political beauty in the now, and might run the risk of depoliticizing action in the political present, because it projects the attainment of political beauty into the un-timed and unknown future. In contrast to most of the earlier theses, Thesis \#9 takes a side, and claims that the personified organic "soul", which has not experienced political beauty, is "lost". In this notion, loss becomes explicitly negative in the sense that loss is bad, and no loss is good. This resignation, and normative tilting towards a non-ambivalent dismissal of loss, which might have still lingered in thesis \#4, morphs the concept of political beauty into a foundational, reified desire to not lose the "poetry" of the "soul".

Finally, Thesis \# 10 builds on the urge for a vitalist understanding of political beauty by introducing the notion of "mental illness" and toxicity, which is proclaimed to occur in the case of no poetry, no soul, or the general absence of political beauty. Thesis \# 10 even more explicitly condemns political ugliness and the lack of political beauty as sickness. Inversely, a soul with poetry or with political beauty would not be sick, but sane and healthy. Sickness must be avoided at any cost; political beauty is indirectly presented as partial cure towards a fullness, which technically continues to persist as lack. This highly problematic, and utterly foundationalist development of the final theses drags the notion of political beauty into a space which is less ambivalent, less interested in the endurance of antagonism, let alone the encouragement thereof. In brief, the last note of the theses leaves a bitter taste in the conceptualization of a conflict-attuned notion of politics that move 'us'.

While the two last theses describe political beauty most explicitly as an absolute or totalizing force against political death and sickness, political beauty is nowhere defined by what it 'is.' Borrowing from Laclau (1990, 44), political beauty might be better understood not by asking "what it is, but what prevents it from being". In that sense, the ZPS manifesto evokes causes that prevent the emergence of political beauty (e.g., loss or absence of a 'soul' or killing of literal or metaphorical butterflies). Political beauty continues to 'be' nothing but a mobilization of idea(l)s and hopes. While there are considerable signs of foundationalist thinking, which is in its own way pathetically romanticist, humanist and vitalist, the theses also appeal to the systemic impossibility and lack of definitive content or location of political beauty. Going beyond the specific theses, the affectivity of political beauty is revealed and invoked as placeless, timeless, caught in constant desire, but also trapped within the impossibility of its own satisfaction. LONGING and lack are co-constitutive of political beauty. Ultimately, political beauty cannot overcome its own ongoing, radical lack. Because lack and absence are constitutive and irreducible to political beauty, all institutions and experiences of such beauty are temporary, precarious, contested, antagonistic. While ZPS' terminology partially essentializes the human or the soul, and is wholly uncritical of the history of science and politics of (mental) illness, relentlessly taking the risk of sounding conservative and absolutist, through my reading of the ten theses, I have attempted to provide a narrative and framework of political beauty that leaves the latter as an irreducibly ambivalent affective imperative against political apathy or general delusion.

\section{Synthesis: Towards a Grammar of Political Beauty?}

To synthesize the offerings of the two grammars of political difference and feeling, the analytical vectors of feeling politics, politics of feeling, politics and the political open both analytical and affective spaces to understand the potential of political beauty. Political beauty itself 'is' nothing - it 'is' empty in the sense of a negative ontology of radical antagonism remaining 'fundamentally' devoid of any distinct meaning, normative value or content. Accordingly, attempts to articulate meanings of political beauty or political affect depend on individual and collective attempts at making meaning, which are always temporary, always precarious and always controversial in their ways of making politics and the political beautiful (or not).

As part of my objective to conceptualize antagonistic affective politics, I have established political beauty as situated within an ontology of negativity and antagonism. This antagonistic approach to politics brings the political back into the grammar of political difference to name, create and transform institutions of politics, but also to imagine forms and actors of the political beyond routinized, sedimented forms of political agency and power. Derived from the political grammar of feelings, feeling politics transmit affective capacities in a variety of ways, provoking emotional responses or sensory imaginaries of feeling healthy, dying, alive or none of the above. Feeling politics function as a modus operandi in the ontic, everyday realm of experiencing 
the socially sedimented weight of the politics of feelings, which embody the rigid, passive, routinized institutions of politics. Like the dislocatory effects of the political, feeling politics dislocate the politics of feelings to make politics experiential, affective (again), and to make feeling more political (again). Ultimately, the political and emotional grammars of difference shed light on the value of political beauty as actualized by affective experiences of the feeling politics and feeling the political. Both enlarge and antagonize, and thus politicize the scope of the political without eliminating or denying the existence of politics. In this unsettling, affective approach to politics, ZPS provides a unique response to contest a supposedly post-political space and time.

This spectral, speculative reading of an affecting text has been a "work in the impasse" (Secor/Linz 2017). Following Ann Cvetkovich $(2012,21)$, my reading in this affective impasse has felt like a "state of both stuckness and potential, maintaining a hopefulness about the possibility that slowing down or not moving forward might not be a sign of failure and might instead be worth exploring". I have attempted to conceptualize political beauty as a temporal, spatial, affective and political category: with regard to the spatiality of antagonistic affective politics, political beauty has been revealed as a concept, practice and affect without beginning, end or location. Political beauty dislocates normalcies and hegemonies, remaining ever unsettling. With regards to the temporality of antagonistic affective politics, political beauty has been shown as nested in temporalities of historically charged pasts, presents and futures, leaping towards futures II, which are full of alternatives, yet burdened by haunted pasts. Political beauty re-configures not only political presents and futures that are not there (yet), but also re-shuffles pasts via the conjuration of new interpretations of what political beauty did or could have done. With regards to the affectivity of antagonistic affective politics, political beauty acts in the face of a lack of foundation, an ongoing lack, surplus, unstoppable desire. Ruch (2012a, 229) intensifies the excessive function of political beauty by stating that "we might be done with beauty, but beauty is not done with us at all". In other words, the urge, and urgency in political beauty will persist. LONGING for political beauty will remain both necessary and unattainable, endlessly entangled in attempts to fill or still Sehnsucht. The continuous desire for political beauty leads to attempts to enact political beauty. At the same time, political beauty remains indeterminate, indeterminable, insatiable and thus irrevocably impossible. As possibility and impossibility, as fullness and absence, political beauty presents both a promise and risk to create affective relations of proximity and distance (see Kemmer 2019).

In sum, the ten theses of political beauty were publicly staged to elicit affective responses to trigger opposition against the assumed neutrality, rationality or non-affective nature of the Bundestag as seat of politics. With this contestation, the narrow and sedimented conception of politics, spatially represented by the Bundestag, has literally and textually been challenged by the appeals to political beauty, oscillating between realms of politics and the political. The performance and text aspire to affectively [un] settle and momentarily displace a meaning of politics, which is portrayed in its post-political diagnosis as apathetic and lacking political imagination. To open both present and future to more political debate and controversy, the performance around the theses aims to actualize antagonism, and to disagree with the diagnosis of post-politics. The spectral reading of the ten theses might uncover a "new topology of the possible" (Rancière 2010,23) with political and emotional contours. The foregrounding of possibilities, alternatives for political beauty reminds of a "conflictual aesthetics" (Marchart 2017), which might make allow us to enact, re-enact and possibly also feel antagonisms. Projecting political beauty as conflictual politics, or politics of antagonism, conflictual aesthetics, or feeling politics of antagonism, qualifies antagonistic affective politics as politics of dissensus to uncover affective traces of power (Bargetz 2014b, 131).

With regards to the negativity of political beauty, my antagonistic conceptualization insists on the damaging inclinations of wanting to classify affects as positive, good, bad or negative. The radical negativity of antagonistic affective politics captures the constitutive contingency, emptiness and antagonism of the category of political beauty, and does not lapse into a valve-driven statement about the kind, quality or direction of affects mobilized via antagonism. With its persistent ambivalence, political beauty appears as a porous concept that both denies and challenges its own impossibility to sustain its own unstoppable potential. Borrowing from Audre Lorde's understanding of "sweaty concepts" as a "battle cry as well as a speaking wound of social misery" (in Slaby 2016, 11), political beauty leaves no clear instructions or programmatic advice about what to do next. It remains inherently non-affirmative as a dislocation of the present, past and future. Breeding the future with a haunted past and present, and attempting the impossible project of political beauty, ZPS invests in (re)opening the future towards ambivalent futures II that will maybe have been politically beautiful. 


\section{Endnotes}

1 https://politicalbeauty.de/pillar.html

2 I consider the differentiation between affect and emotion/feeling important, yet, difficult to disentangle analytically with regards to their (pre)cognitive and (trans)individual scope (see Ahmed 2014; Hemmings 2005; Leys 2011). Generally, affects can ignite politicizing and depoliticizing, emancipatory and reactionary, conservative and liberal political attitudes and actions (see Berlant 2011). While emotions and affects are not synonymous, they are also not completely independent from each other. For example, Hemmings (2005) points out, it is precisely the limitation or situatedness of affect's autonomy that makes it not autonomous from bodily experience or emotion. These ambivalent lines between affect and emotions guide my conceptualization of affective politics.

3 Deleuze's (2003) notion of vitality and passive vitalism could be engaged in conceptualizing this vignette. Due to the negative ontology of antagonism employed in this paper, which might result in assuming Deleuze's vitalism as a kind of intensive foundationalism, I do not explore his notion further.

4 The life or liveliness argument reminds of another controversially interpreted Deleuzo-Guattarian concept, the 'inorganic life' (see Dema 2007), which shall not be discussed further in this specifically post-foundational analysis. A Deleuzian reading of the theses or the 'value' of political beauty would however be intriguing. 


\section{Literature}

Ahmed, Sara. 2014. Affect/Emotion: Orientation Matters. A conversation with Sigrid Schmitz and Sara

Ahmed. Freiburger Zeitschrift für GeschlechterStudien 28, no. 2: 97-108.

Ahmed, Sara. 2015. The cultural politics of emotion. Second edition. New York: Routledge.

Anderson, Ben. 2014. Encountering affect. Capacities, apparatuses, conditions. Farnham, Surrey, Burlington, VT: Ashgate.

Angerer, Marie-Luise; Bernd Bösel; Michaela Ott (ed.) 2014. Timing of Affect. Epistemologies, Aesthetics, Politics. Zurich: Diaphanes.

Barad, Karen. 2003. Posthumanist Performativity. Toward an Understanding of How Matter Comes to Matter. Signs: Journal of Women in Culture and Society 28, no. 3: 801-831.

Bargetz, Brigitte. 2013. Markt der Gefühle, Macht der Gefühle. Konturen eines emotionstheoretischen Machtverständnisses. In: Österreichische Zeitschrift für Soziologie 38, no. 2: 203-220.

Bargetz, Brigitte. 2014a. Mapping Affect. Challenging of (Un)Timely Affect. In: Timing of Affect. Epistemologies, Aesthetics, Politics, 289-302. Zurich: Diaphanes.

Bargetz, Brigitte. 2014b. Jenseits emotionaler Eindeutigkeiten. Überlegungen zu

einer politischen Grammatik der Gefühle. In: Affekt und Geschlecht. Eine einführende Anthologie, 117-137. Vienna: Zaglossus.

Bargetz, Brigitte. 2015. The Distribution of Emotions. Affective Politics of Emancipation. Hypatia 30, no. 3: 580-596.

Bargetz, Brigitte. 2018. Der sentimentale Vertrag

Eine politische Theorie der Affekte und das unvollendete liberale Projekt. Leviathan. Berliner Zeitschrift für Sozialwissenschaft, no. $46: \mathrm{n} / \mathrm{a}$.

Bargetz, Brigitte; Freudenschuss, Magdalena. 2012. Der emotionale Aufstand Verhandlungen um eine Politik der Gefühle in Zeiten der Krise. In: Femina Politica. Zeitschrift für feministische Politikwissenschaft., 107-114.

Berlant, Lauren Gail. 2011. Cruel optimism. Durham: Duke University Press.

Bayrischer Rundfunk. 2014. Aktionskunst zur Rettung von syrischen Kindern: Available at: https://www.br.de/radio/bayern2/sendungen/kulturjournal/zentrum-fuer-politische-schoenheit-104.html

Beveridge, Ross. 2017. The (Ontological) Politics in Depoliticisation Debates. Three Lenses on the Decline of the Political. Political Studies Review 42, no. 2: 589-600.

Beveridge, Ross; Koch, Philippe. 2016. The post-political trap? Reflections on politics, agency and the city. Urban Studies 54, no. $1: 31-43$.

Bhaba, Homi. 1994. The Location of Culture. New York: Routledge.

Blackman, Lisa. 2015. The Haunted Life of Data. In Compromised Data From Social Media to Big Data, 185-209. Oxford: Bloomsbury, London.

Blanco, María del Pilar; Peeren, Esther. 2013. The spectralities reader. Ghosts and haunting in contemporary cultural theory. London: Bloomsbury Academic.

Colebrooke, Claire. 2014. Sex After Life - Essays on Extinction, Vol. 2. Michigan: Open Humanities Press.

Crouch, Colin. 2014. Post-democracy. Cambridge: Polity Press.

Cvetkovich, Ann. 2007. Public Feelings. South Atlantic Quarterly 106, no. 3: 459-468.

Cvetkovich, Ann. 2012. Depression - A Public Feeling. Durham and London: Duke University Press.

Davidson, Mark; Iveson, Kurt. 2014. Recovering the politics of the city. Progress in Human Geography 39, no. 5: 543-559.

Deleuze, Gilles and Félix Guattari. 2003. Was ist Philosophie? Frankfurt / Main: Suhrkamp.

Dema, Leslie. 2007. "Inorganic, Yet Alive": How Can Deleuze and Guattari Deal With the Accusation of Vitalism? Available at: http://www.rhizomes.net/issue 15/dema.html 
Derrida, Jacques; Kamuf, Peggy. 1994. Specters of Marx. The state of the debt, the work of mourning, and the new international. New York, NY: Routledge (Routledge classics).

Gordon, Avery. 2008. Ghostly matters. Haunting and the sociological imagination. Minneapolis: University of Minnesota Press.

Gordon, Avery. 2011. Some Thoughts on Haunting and Futurity. Borderlands 10, no. 2: 1-21.

Gregg, Melissa; Seigworth, Gregory J. 2011. The affect theory reader. North Carolina: Duke University Press.

Harrison, Paul. 2015. After Affirmation, or, Being a Loser. On Vitalism, Sacrifice, and Cinders. Geo-Humanities 1, no. 2 : 285-306.

Hemmings, Clare. 2005. Invoking Affect. Cultural theory and the ontological turn. Cultural Studies 19 no. 5: $548-567$.

Kemmer, Laura. 2019. Promissory things: how affective bonds stretch along a tramline, Distinktion: Journal of Social Theory.

Knudsen, Britta Timm; Stage, Carsten. 2015. Affective Methodologies. Developing Cultural Research Strategies for the Study of Affect. London: Palgrave Macmillan UK.

Laclau, Ernesto. 1990. New reflections on the revolution of our time. London, New York: Verso (Phronesis).

Laclau, Ernesto. 2007. On populist reason. London, New York: Verso.

Laclau, Ernesto; Mouffe, Chantal. 2001. Hegemony and socialist strategy. Towards a radical democratic politics. 2 nd edition. London, New York: Verso.

Landau, Friederike. 2019a. Agonistic Articulations in the ,Creative' City - On New Actors and Activism in Berlin's Cultural Politics. London: Routledge.

Landau, Friederike. 2019b. (Dis)Assembling Borders - On the Affective Politics of Artistic Activism. Forthcoming

Landau, Friederike; Roskamm, Nikolai. 2018. [Un]Settling the City. In: engagée,

radical cities: $73-77$.

Larner, Wendy. 2015. The Limits of Post-Politics: Rethinking Radical Social Enterprise. The post-political and its discontents. Spaces of depoliticisation, spectres of radical politics: 189-208.

Lefort, Claude (1988): Democracy and political theory. Cambridge: Polity.

Leys, Ruth. 2011. The Turn to Affect. A Critique. Critical Inquiry 37, no. 3: 434-472.

Marchart, Oliver. 2010. Die politische Differenz. Zum Denken des Politischen bei

MDR Thüringen. 2019. Vorwurf der Bildung einer kriminellen Vereinigung. Ermittlungen gegen „Zentrum für politische Schönheit" eingestellt. Available at: https://www.mdr.de/thueringen/ermittlungsverfahren-zentrum-poli tische-schoenheit-eingestellt-100.html

Nancy, Lefort, Badiou, Laclau und Agamben. Frankfurt am Main: Suhrkamp.

Marchart, Oliver. 2013. Das unmögliche Objekt. Eine postfundamentalistische Theorie der Gesellschaft. Berlin: Suhrkamp.

Marchart, Oliver. 2017. Conflictual Aesthetics. Berlin: Sternberg.

Massumi, Brian. 2002. Parables for the Virtual: Movement, Affect, Sensation. Duke: Duke University Press.

Massumi, Brian. 2015. The politics of affect. Cambridge, Malden, MA: Polity.

Mouffe, Chantal. 2013. Agonistics. Thinking the World Politically. Verso.

Mouffe, Chantal. 2006. Religion, Liberal Democracy, and Citizenship. In: Hent de Vries und Lawrence E. Sullivan (Hg.): Political Theologies: Fordham University Press: 318-326.

Mouffe, Chantal. 2005. On the political. London, New York: Routledge.

O Riley, Michael. 2007. Postcolonial Haunting: Anxiety, Affect, and the Situated Encounter. Post-colonial Text 3, no.4: 1-15.

Pile, Stephen. 2005. Spectral Cities: Where the Repressed Returns and Other Short Stories. In: Habitus: A sense of place, 219-239. Sydney: Ashgate.

Protevi, John. 2009. Political affect. Connecting the social and the somatic. Minneapolis, MN: University of Minnesota Press. 
Rancière, Jacques. 2010. Dissensus. On Politics and Aesthetics. London: Bloomsbury.

Reestorff, Camilla M. 2015: From Artwork to Net-work: Affective Effects of Political Art. In: Affective Methodologies, 201-222.

Roberts, Elisabeth. 2013. Geography and the visual image. Progress in Human Geography 37, no. 3: 386-402.

Roskamm, Nikolai. 2017. Unbesetzte Stadt. Postfundamentalistisches Denken und das Urbanistische Feld. Basel: Birkhäuser.

Ruch, Philipp. 2012a. Beauty in the Political Sciences. The Insufficiency of Contemporary Accounts and the Premature Death of the Category. In Reclaiming Beauty: Collected Essays in Political Anthropology: Volume I, 211 -237. Florence, Italy: Ficino Press.

Ruch, Philipp. 2012b. Was ist politische Schönheit? Die Zukunft als Nährboden der höchsten Form aller Künste: Ein Essay. In Politik trifft Kunst. Zum Verhältnis von politischer und kultureller Bildung. Schriftenreihe Band 1242: 94-103.

Secor, Anna; Linz, Jess. 2017. Becoming minor. Environment and Planning D 35, no. 4: 568-573.

Sedgwick, Eve Kosofsky; Frank, Adam. 2003. Touching feeling. Affect, pedagogy, performativity. Durham: Duke University Press.

Sharpe, Christina. 2016. In the Wake: On Blackness and Being. Durham: Duke University Press.

Slaby, Jan. 2016. Drei Haltungen der Affect Studies. Unpublished Manuscript.

Slaby, Jan. 2017a. More than a Feeling: Affect as Radical Situatedness. Midwest Studies in Philosophy XLI: 7-26.

Slaby, Jan. 2017b. Affective Arrangements and Disclosive Postures: Towards a Post-Phenomenology of Situated Affectivity.

Spinoza, Benedict, de. 2009. Ethics. Project Gutenberg. dele

Swyngedouw, Erik. 2009. The Antinomies of the Postpolitical City. In Search of a Democratic Politics of Environmental Production. International Journal of Urban and Regional Research 33, no. 3: 601-620.

Swyngedouw, Erik. 2011. Interrogating post-democratization: Reclaiming egalitarian political spaces. Political Geography 30, 2011: 370-380.

Swyngedouw, Erik. 2016. Unlocking the mind-trap. Politicising urban theory and practice. Urban Studies 54, no. 1: 55-61.

Watson, David, Clark, Lee A., and Tellegen, Auke. 1988. Development and validation of brief measures of positive and negative affect: The PANAS scales. Journal of Personality and Social Psychology 54: 1063-1070.

Wilson, Japhy; Swyngedouw, Erik (ed.) 2014. The post-political and its discontents. Spaces of depoliticisation, spectres of radical politics. Edinburgh: Edinburgh University Press.

Wylie, John. 2007. The spectral geographies of W.G. Sebald. cultural geographies 14, no. 2: 171- 188.

Žižek, Slavoj. 2009a. The parallax view. Cambridge, Massachusetts: MIT.

Žižek, Slavoj. 2009b. The ticklish subject. The absent centre of political ontology. London: Verso.

Zentrum für Politische Schönheit. 2009a. Portfolio. Available at: https://issuu.com/philippruch/docs/portfolio 2009

Zentrum für Politische Schönheit. 2009b. Aktionen. Available at: https://www.politicalbeauty.de/reformation.html

Zentrum für Politische Schönheit. 2019, February 27, personal conversation, Berlin. 